\title{
The evaluation of cycle by cycle mixture composition in an indirect injection engine
}

\begin{abstract}
The investigations on an indirect injection unsupercharged engine fitted with a two state oxygen sensor have shown a particularly high fluctuation of mixture composition in transient states of the engine, represented by the rev up and rev down of the engine without a load and with a steady load. The spread of the maximum and average cycle by cycle mixture compositions in these states determined by a method developed by the authors (this method shall be a subject of a separate publication) is larger if the engine load is lower. It has been proved that the biggest fluctuation of the mixture composition occurs in the first part of the rev down phase i.e. in the phase of stepwise throttle closing when the injectors are still activated. In steady states represented by typical operating states of the engine the highest fluctuation of the mixture composition occurs at high engine speeds and low engine loads, and the lowest at low engine speeds and high engine loads. It has been confirmed that the fluctuation of the cycle by cycle mixture composition in the transient states is almost one order of magnitude larger than in the steady states. The investigations have been performed on a $1.6 l$ Euro 3 engine fitted with a control unit made by a reputable manufacturer.
\end{abstract}

Keywords: gasoline engine, mixture composition, non-repeatability of the mixture composition

\section{Ocena fluktuacji cyklowego składu mieszanki w silniku z pośrednim wtryskiem benzyny}

Badania silnika wolnossącego z wtryskiem pośrednim benzyny z dwustanowa sonda lambda wykazaly szczególnie wysoka fluktuację sktadu mieszanki w stanach przejściowych w silniku, reprezentowanych przez rozbieg $i$ wybieg silnika bez obciażenia i ze stałym obciążeniem. Rozrzuty maksymalny i średni cyklowego składu mieszanki w tych stanach wyznaczone opracowana we wtasnym zakresie metoda (będzie to przedmiotem odrębnej publikacji) sa tym większe, im obciążenie silnika jest mniejsze. Wykazano, że największa fluktuacja składu ma miejsce w pierwszej części fazy wybiegu, tj. $w$ fazie skokowego zamykania przepustnicy, kiedy wtryskiwacze nie sa jeszcze wyłaczone. W stanach ustalonych reprezentowanych przez typowe stany eksploatacyjne silnika najwyższa fluktuacja sktadu wystepuje na wysokich obrotach silnika z niskim obciązeniem, a najmniejsza w silniku wysokoobciążonym na niskich obrotach. Stwierdzono, że fluktuacja składu cyklowego mieszanki w stanach przejściowych jest prawie o jeden rząd większa niż w stanach pracy ustalonej. Badania wykonano na silniku o pojemności $1.6 l$ z ważna homologacja Euro 3, wyposażonym w system sterowania znanej światowej firmy.

Słowa kluczowe: silnik benzynowy, skład mieszanki, niepowtarzalność składu mieszanki

\section{Introduction}

The biggest obstacle in ensuring repeatability in the mixture composition, having the biggest influence on the efficiency of a three way catalytic converter is the fuel film characteristics of indirect injection engines. Its existence, particularly in the transient states causes the mixture that reaches the catalyst to be different from the originally calculated mixture. If the calculated mixture composition (preset) does not allow for the dynamic properties of the fuel film the exhaust gas emissions past the catalyst will grow.

One of the ways to resolve this issue is based on the idea of combining two methods of mixture composition control i.e. open control (map) and closed control (adjustment) with the oxygen sensor feedback in the exhaust pipe. The first, based on the selected quantities characterizing the engine state determine the initial value of the mixture composition and the other adjusts that value to the expected one corresponding to the air excess coefficient $\lambda^{*}=1.0$ in the exhaust gases.

\section{Wprowadzenie}

Największą przeszkodą w zapewnieniu powtarzalności składu mieszanki spalonej, mającego największy wpływ na efektywność pracy trójfunkcyjnego reaktora katalitycznego, jest film paliwowy, będący właściwością silników z wtryskiem pośrednim paliwa. Jego istnienie powoduje, że zwłaszcza w stanach przejściowych skład mieszanki docierający do reaktora katalitycznego jest różny od składu wysterowanego. Jeżeli skład wysterowany nie uwzględni dynamicznych właściwości filmu paliwowego, toksyczność spalin za katalizatorem wzrośnie.

Jeden ze sposobów rozwiązania tego problemu polega na połączeniu dwóch metod sterowania składem mieszanki, tj. tzw. sterowania otwartego (wg tzw. map) i sterowania zamkniętego (regulacji) z czujnikiem tlenu w spalinach (tzw. sondą lambda) w sprzężeniu zwrotnym. Pierwsze z nich, w oparciu o wybrane wielkości charakteryzujące stan silnika, wyznacza wartość początkową składu mieszanki, a drugie koryguje tę wartość do oczekiwanej, której odpowiada współczynnik nadmiaru powietrza określony w spalinach $\lambda^{*}=1,0$. 
The purpose of own investigations in this area, whose results have been presented in this publication is such a control of the mixture composition in an indirect injection engine that will ensure a combustion of a stoichiometric mixture in each cycle of the combustion in each cylinder taking into account the properties of the fuel film.

For the determining of the dynamic properties of the fuel film the methods of determining (measurement, calculation, forecasting) of the mixture composition are necessary: preset composition and a composition determined based on the exhaust gases in a single cycle. In the publication the authors present their own method of determining of the cycle by cycle preset mixture composition and in further publications the authors will discuss the way of determining of the mixture composition reaching the catalyst.

\section{Expected features of a spark ignition engine control system}

Exhaust gas emissions, operating energy consumption and the controllability are the three basic characteristics of a car that are influenced by the engine control system.

An ecological mixture is a mixture whose combustion in an engine operating under emission homologation test conditions (e.g. ECE-15 R.83) will ensure meeting $i$ requirements (1) at the same time:

$$
\int^{\mathrm{T}} \mathrm{m}_{\mathrm{i}}(\mathrm{t}) \mathrm{dt} \leq \mathrm{M}_{\mathrm{i}}^{*}
$$

where: $m_{i}(t)-$ mass flow rate of $i$-th toxic component, $M_{i}^{*}$ - maximum admissible mass of $i$-th component during the test, $\mathrm{T}-$ test duration, $\mathrm{i}-\mathrm{HC}+\mathrm{NO}_{\mathrm{x}}, \mathrm{CO}$ (for ECE-15 R.83 v. 01-04).

One of the ways to reduce the exhaust emissions is the application of a three way catalytic converter, whose efficiency is the highest when the exhaust gases flowing through the catalyst are a result of a combustion of a stoichiometric mixture. The range of the highest catalytic converter efficiency is very narrow (Fig. 1) [1].

This imposes on the mixture composition control system a requirement of ensuring a full and entire combustion in each cycle in each cylinder. A failure to fulfill this condition results in a necessity of seeking other ways to reduce exhaust emissions, which complicate the engine design and increase the costs of manufacturing.

We should note that the application of a catalytic converter is also justified if $\lambda \neq 1.0$ but the extent of its usage and its durability are lower than in the case when $\lambda=1.0$. This way of the catalytic converter application can be considered in cases where it reduces fuel consumption at the same time fulfilling requirements (1).

An economical mixture is a mixture whose composition ensures combustion with the smallest specific fuel consumption under given conditions (2):

$$
\mathrm{g}_{\mathrm{e}}=\frac{\mathrm{m}_{\mathrm{f}}}{\mathrm{N}_{\mathrm{e}}}=\min
$$

Celem prowadzonych w tym obszarze badań własnych, których wybrane wyniki przedstawiono w tej publikacji, jest takie sterowanie składem mieszanki w silniku z wtryskiem pośrednim, które, uwzględniając właściwości filmu paliwowego, zapewni spalanie mieszanki stechiometrycznej w każdym cyklu spalania, w każdym z cylindrów.

Do wyznaczenia dynamicznych właściwości filmu paliwowego niezbędne są metody wyznaczania (pomiaru, obliczania, prognozowania) składów mieszanki: wysterowanego i określonego w oparciu o spaliny na poziomie pojedynczego cyklu. W przygotowywanej do druku publikacji zaprezentowano własną metodę wyznaczania cyklowego, wysterowanego składu mieszanki, a w kolejnych publikacjach przedstawiony będzie sposób wyznaczania składu mieszanki docierającej do reaktora katalitycznego.

\section{Oczekiwane cechy sterowania silnikiem o zapłonie iskrowym}

Toksyczność spalin, eksploatacyjna energochłonność oraz sterowalność to trzy podstawowe cechy samochodu, na które zasadniczy wpływ ma sterowanie silnika.

Mieszanka ekologiczna to taka mieszanka, której spalanie w silniku pracującym w warunkach testu homologacyjnego na toksyczność spalin (np. ECE-15 R.83) zapewni spełnienie $i$ warunków (1) równocześnie - równanie (1), gdzie: $\mathrm{m}_{\mathrm{i}}(\mathrm{t})$ masowe natężenie przepływu i-tego toksycznego składnika, $\mathrm{M}_{\mathrm{i}}^{*}$ - dopuszczalna całkowita masa i-tego składu w silniku $\mathrm{w}$ teście, $\mathrm{T}-$ czas trwania testu, $\mathrm{i}-\mathrm{HC}+\mathrm{NO}_{\mathrm{x}}$, $\mathrm{CO}$ (dla ECE-15 R.83 v. 01-04).

Jednym ze sposobów ograniczania emisji toksycznych składników w spalinach jest stosowanie trójfunkcyjnego reaktora katalitycznego, którego efektywność jest największa, jeżeli spaliny przepływające przez katalizator są wynikiem spalania mieszanki stechiometrycznej. Przedział największej efektywności katalizatora jest niezwykle wąski (rys. 1) [1].

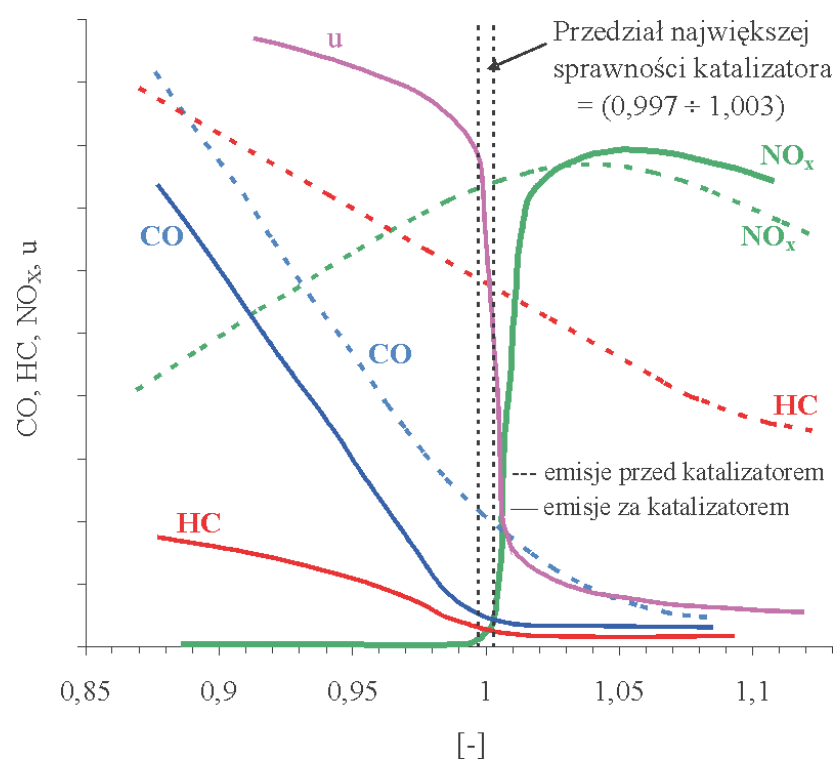

Fig. 1. The efficiency of a three way catalytic converter [1] Rys. 1. Skuteczność trójfunkcyjnego reaktora katalitycznego [1] 
In conventional engines the fuel consumption as per criterion (2) leads to a growth in the level of $\mathrm{HC}$ emissions as a result of misfired cycles or cycles with inappropriate combustion. If the engine is ready to combust lean mixtures (in the German language: Magermotor, and in the English language Lean Engine) a reduction in the emission of $\mathrm{HC}$, $\mathrm{CO}$ and $\mathrm{NO}_{\mathrm{x}}$ takes place along with the reduction of specific fuel consumption $g_{\mathrm{e}}$.

In order to ensure a required dynamics of a vehicle the change of torque $\Delta \mathrm{M}$ of the engine should correspond to the preset mixture values measured by the speeds of $\mathrm{d} \alpha / \mathrm{dt}$ throttle opening and the level of its opening $\Delta \alpha$. English sources came up with a term of driveability that is an equivalent of a German Farhbarkeit - a term that denotes those engine features that describe the way the engine speed is changed through changing the throttle opening angle by the driver. In the Polish language the closets term would be „sterowalność". The literature does not have a precise definition and interpretation of this feature of an engine. We need to attempt to describe it using methods applied in automatics for non-linear objects under transient states. In a general sense, in the attempts to describe this engine s feature we need to connect the increment of $\Delta \vec{U}$ with the resultant change $\Delta \vec{X}$ of the state of the object (3):

$$
\mathrm{s}=\mathrm{f}\left(\Delta \overrightarrow{\mathrm{U}}, \frac{\Delta \overrightarrow{\mathrm{U}}}{\mathrm{dt}}, \Delta \overrightarrow{\mathrm{X}}, \frac{\Delta \overrightarrow{\mathrm{X}}}{\mathrm{dt}}\right)
$$

From the mathematical description of this engine feature it should result that the best (the largest) engine drivability should fall with the engine point of work with the highest volumetric efficiency and in any given point of its work $n \times M$ if the mixture has a dynamic composition i.e. ensuring the quickest combustion.

The purpose of the determined optimum control is to ensure a consensus within the above structurally contradictory expectations (1)-(3). This consensus is reached as a result of adopting a criterion of control optimization(4):

$$
\mathrm{M}_{\mathrm{F}}=\int^{\mathrm{T}} \mathrm{m}_{\mathrm{f}}(\mathrm{t}) / \mathrm{dt}=\min \quad \mathrm{dla} \quad \mathrm{t} \in \mathrm{T}
$$

where: $\mathrm{T}-$ test duration, $\mathrm{m}_{\mathrm{f}}-$ mass fuel expenditure used by the engine.

This criterion ensures a minimization of mass $\mathrm{M}_{\mathrm{F}}$ of the fuel used in the test while requirements (1) and (3) are fulfilled. This is obvious that the mass of the fuel used by the engine during the test controlled according to criterion (2) would be lower than if it were controlled by criterion (4) and requirements (1) and (3) would not be fulfilled.

The results of solving the task according to (1), (3), (4) is a vector of the optimum control $\overrightarrow{\mathrm{U}^{0}}$ according to (5):
Nakłada to na system sterowania składem mieszanki wymaganie zapewnienia pełnego i zupełnego spalania $\mathrm{w}$ każdym cyklu każdego z cylindrów. Niespełnienie tego warunku powoduje konieczność stosowania innych sposobów ograniczania toksyczności spalin, prowadzących do skomplikowania konstrukcji silnika i wzrostu kosztów jego produkcji.

Należy zauważyć, że stosowanie katalizatora jest również zasadne w przypadku, gdy $\lambda \neq 1,0$, przy czym stopień jego wykorzystania i trwałość są wtedy mniejsze niż przy $\lambda=1,0$. Ten sposób jego wykorzystania można brać pod uwagę $w$ tych przypadkach, w których powoduje to obniżenie zużycia paliwa, z jednoczesnym spełnieniem ograniczeń (1).

Mieszanka ekonomiczna to mieszanka, której skład zapewnia spalanie $\mathrm{z}$ najmniejszym $\mathrm{w}$ danych warunkach jednostkowym zużyciem paliwa - równanie (2).

W silnikach konwencjonalnych spalanie wg kryterium (2) prowadzi do wzrostu poziomu emisji $\mathrm{HC}$ w wyniku cykli bez spalania bądź ze spalaniem nieprawidłowym. Jeżeli silnik jest odpowiednio dostosowany do spalania tzw. mieszanek ubogich (niem. Magermotor, ang. Lean Engine), występuje równoczesne obniżenie emisji $\mathrm{HC}, \mathrm{CO}$ i NO $\mathrm{x}_{\mathrm{x}}$ oraz jednostkowego zużycia paliwa $\mathrm{g}_{\mathrm{e}}$.

Dla zapewnienia wymaganej dynamiki samochodu zmiana momentu $\Delta \mathrm{M}$ silnika powinna być adekwatna do wysterowania, którego miarą mogą być szybkość da/ dt otwierania przepustnicy oraz stopień jej otwarcia $\Delta \alpha$. W literaturze anglojęzycznej wprowadzono pojęcie driveability, któremu w języku niemieckim odpowiada Farhbarkeit dla określenia tych cech silnika, które opisują sposób zmiany prędkości obrotowej w silniku w wyniku wymuszenia ze strony kierowcy w postaci zmiany kąta otwarcia przepustnicy powietrza. W języku polskim najbliższa temu określeniu jest „sterowalność”. Brak jest w literaturze tematu jednoznacznej definicji i interpretacji tej cechy silnika. Należy zmierzać do jej opisu z wykorzystaniem metod stosowanych w automatyce dla obiektów nieliniowych w stanach przejściowych. W ogólnym przypadku, w próbach opisania tej cechy s silnika należy wiązać przyrost wymuszenia $\Delta \vec{U}$ ze spowodowaną przez nie zmianą $\Delta \overrightarrow{\mathrm{X}}$ stanu obiektu - równanie (3).

$\mathrm{Z}$ opisu matematycznego tej cechy silnika powinno wynikać, że najlepsza (największa) sterowalność silnika ma miejsce dla punktu pracy z największą sprawnością wolumetryczną, a $w$ dowolnym punkcie jego pracy $n \times M$ wtedy, gdy mieszanka będzie miała tzw. skład dynamiczny, tj. zapewniający największą szybkość spalania.

Zadaniem wyznaczonego sterowania optymalnego jest zapewnienie konsensusu w ramach sformułowanych wyżej sprzecznych strukturalnie oczekiwań (1)-(3). Konsensus ten jest osiągany w wyniku przyjęcia kryterium optymalizacji sterowania $\mathrm{w}$ postaci (4), gdzie: $\mathrm{T}$ - czas trwania testu, $\mathrm{m}_{\mathrm{f}}$ - masowy wydatek paliwa zużywanego przez silnik.

Kryterium to zapewnia minimalizację masy $\mathrm{M}_{\mathrm{F}}$ zużytego $\mathrm{w}$ teście paliwa przy równoczesnym spełnieniu ograniczeń (1) i (3). To oczywiste, że masa paliwa zużytego przez silnik 


$$
\overrightarrow{\mathrm{U}^{0}}=\left[\begin{array}{c}
\mathrm{u}_{\mathrm{i}} \\
\vdots \\
\mathrm{u}_{\mathrm{q}}
\end{array}\right]
$$

The bigger the size of this vector the more complex is the solution of the task. In publication [2] a full procedure of determining of the two dimensional control (mixture composition $\lambda$ ignition advance angle $\delta$ ) has been described for a 1.61 gasoline engine.

\section{Exemplification of control in an open-closed system}

The control (5) can be realized in an open and closed systems: open [3], closed, i.e. adjustment, or currently almost exclusively applied - a mixed system where the vector (5) takes a form of (6):

$$
\overrightarrow{\mathrm{U}}=\left[\begin{array}{c}
\overrightarrow{\mathrm{U}}_{\mathrm{r}} \\
\overrightarrow{\mathrm{U}}_{\mathrm{s}}
\end{array}\right]
$$

where: $\vec{U}_{\mathrm{s}}-$ control vector, $\overrightarrow{\mathrm{U}}_{\mathrm{r}}$-adjustment vector.

In the exemplification as per (6) (Fig. 2) the control $\vec{U}_{s}$ ensures an initial state $\vec{X}_{0}$ of the controlled process in an open system using a map as per (7), developed on the system calibration stage:

$$
\overrightarrow{\mathrm{U}}_{0}=\overrightarrow{\mathrm{U}}_{\mathrm{s}}\left(\overrightarrow{\mathrm{Y}}_{0}\right) \text { dla } \overrightarrow{\mathrm{Y}}_{0} \in \overrightarrow{\mathrm{X}}
$$

And the control $\vec{U}_{\mathrm{r}}$ adjusts-in a feedback system - the current state of $\vec{X}$ of the object to an expected state $\vec{X}^{0}$ :

$$
\overrightarrow{\mathrm{U}}_{\mathrm{k}}=\overrightarrow{\mathrm{U}}_{\mathrm{r}}\left(\overrightarrow{\mathrm{Y}}_{\mathrm{k}}\right) \text { dla } \overrightarrow{\mathrm{Y}}_{\mathrm{k}} \in \overrightarrow{\mathrm{X}}
$$

An example of such a control is the MOTRONIC system commonly applied by European vehicle manufacturers, where:

$$
\overrightarrow{\mathrm{U}}_{0}=\left[\begin{array}{l}
\mathrm{T}_{0} \\
\delta_{0} \\
\operatorname{egr} \\
\vdots \\
\mathrm{u}_{\mathrm{q}}
\end{array}\right] \quad \overrightarrow{\mathrm{U}}_{\mathrm{k}}=\left[\begin{array}{c}
\mathrm{T}_{\mathrm{k}}(\lambda) \\
\delta_{\mathrm{k}}\left(\mathrm{i}_{\mathrm{c}}\right)
\end{array}\right]
$$

where: $\mathrm{T}_{0}, \delta_{0}-$ initial injection values $\left(\mathrm{T}_{0}\right)$ and ignition advance angle $\left(\delta_{0}\right)$, egr - exhaust recirculation coefficient, $\mathrm{u}_{\mathrm{q}}$ - other control components, $\mathrm{T}_{\mathrm{k}}(\lambda)$ - length of the adjusted injection depending on the air excess coefficient in the exhaust gases, $\delta_{k}\left(i_{c}\right)$-adjusted ignition angle depending on the level of knocking combustion $i_{c}$. w teście, sterowanego wg kryterium (2) byłaby mniejsza niż wg kryterium (4), przy czym nie byłyby wtedy spełnione warunki (1) i (3).

Wynikiem rozwiązania zadania wg (1), (3), (4) jest wektor optymalnego sterowania $\overrightarrow{\mathrm{U}^{0}} \mathrm{wg}(5)$.

Im wymiar tego wektora jest wyższy, tym sposób rozwiązania tego zadania jest bardziej złożony. W publikacji [2] przedstawiono pełną procedurę wyznaczania sterowania dwuwymiarowego (skład mieszanki $\lambda$ i kąt wyprzedzenia zapłonu $\delta$ ) dla silnika benzynowego o pojemności $1.6 \mathrm{dm}^{3}$.

\section{Egzemplifikacja sterowania w układzie otwarto-zamkniętym}

Sterowanie (5) może być zrealizowane w systemach sterowania: otwartego [3], zamkniętego, tj regulacji, bądź co jest aktualnie stosowane prawie wyłącznie - w układzie mieszanym, w którym wektor (5) przyjmuje postać (6), gdzie: $\vec{U}_{\mathrm{s}}$ - wektor sterowania, $\overrightarrow{\mathrm{U}}_{\mathrm{r}}$ - wektor regulacji.

W egzemplifikacji według (6) (rys. 2) sterowanie $\vec{U}_{s}$ zapewnia stan początkowy $\overrightarrow{\mathrm{X}}_{0}$ sterowanego procesu $\mathrm{w}$ układzie otwartym, korzystając z tzw. map wg (7), opracowanych na etapie kalibracji systemu, a sterowanie $\vec{U}_{r}$ koryguje - w układzie ze sprzężeniem zwrotnym - bieżący stan $\vec{X}$ obiektu do stanu oczekiwanego $\vec{X}_{0}$ (8).

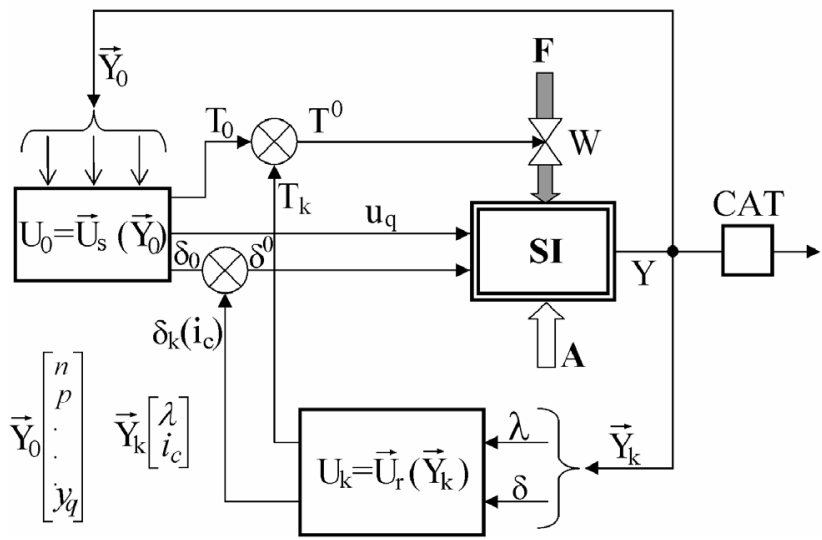

Fig. 2. The idea of control in an open-closed system with a two dimensional adjustment vector

Rys. 2. Istota sterowania w systemie otwarto-zamkniętym z dwuwymiarowym wektorem regulacji

Przykładem takiego sterowania jest system MOTRONIC stosowany powszechnie przez europejskich producentów samochodów - równanie (9), gdzie: $\mathrm{T}_{0}, \delta_{0}$ - wartości początkowe wtrysku $\left(\mathrm{T}_{0}\right)$ i kąta wyprzedzenia zapłonu $\left(\delta_{0}\right)$, egr - współczynnik recyrkulacji spalin, $\mathrm{u}_{\mathrm{q}}$ - inne składowe sterowania, $T_{k}(\lambda)$ - długość wtrysku korekcyjnego zależna od współczynnika nadmiaru powietrza w spalinach, $\delta_{k}\left(i_{c}\right)$ - korekcyjny kąt wyprzedzenia zapłonu zależny od intensywności i spalania stukowego. 
The first component i.e. $\mathrm{T}_{\mathrm{k}}(\lambda)$ maintains the mixture composition under given engine states on the level of $\lambda^{*}=1$, which is vital for the level of individual toxic compounds as per (1). The second component of the adjustment vector, i.e. $\delta_{k}\left(i_{c}\right)$ seeks the maximum energetic efficiency of the process as a result of seeking of a maximum engine torque (boundary value $i_{c}$ ). In the first case the system operates in a system of steady $\lambda^{*}=1$ value stabilization and in the second in a extreme adjustment system $\mathrm{M}\left(\delta^{\mathrm{E}}\right)=\max$.

\section{The control features in the tested engine}

In the test engine the initial control $\overrightarrow{\mathrm{U}}_{0}$ as per (10) determines the initial state $\vec{X}_{0}$ as a result of the initial injection $\mathrm{T}_{0}$ and the ignition advance angle $\delta$ :

$$
\overrightarrow{\mathrm{U}}_{0}=\overrightarrow{\mathrm{U}}_{\mathrm{s}}\left|\begin{array}{l}
\mathrm{n} \\
\mathrm{p}_{\Sigma} \\
v_{\mathrm{E}}
\end{array}\right|=\left[\begin{array}{l}
\mathrm{T}_{0} \\
\delta
\end{array}\right]
$$

using:

- engine speed $n$,

- pressure in the intake manifold $\mathrm{p}_{\Sigma}$,

- engine block temperature $v_{\mathrm{E}}$.

Adjustment control 1-dimensional ${\overrightarrow{U_{k}}}_{k}$ as per (11):

$$
\overrightarrow{\mathrm{U}_{\mathrm{k}}}=\overrightarrow{\mathrm{U}_{\mathrm{r}}}|\lambda|=\mathrm{T}_{\mathrm{K}}
$$

stabilizes the mixture composition on the level of $\lambda^{*}=1.0$ in all those cases where the initial control $\vec{U}_{0}$ as per the maps does not ensure (for a variety of reasons) the expected mixture compositions.

We should expect that a mixed control $\vec{U}_{s}$ as per (6) will be advantageous because it uses:

- open control $\vec{U}_{0}$ as per (10) in the transient states ensuring a higher speed of setting up of the initial state of object $\overrightarrow{\mathrm{X}}_{0}$, (as opposed to adjustment control) limited only by the speed of the measurement of the state of $\overrightarrow{\mathrm{Y}}_{0}$ and the speed of the actuators,

- in steady states, closed control $\vec{U}_{k}$ as per (11) with the use of oxygen sensor, that should eliminate the deviation of the mixture composition irrespective of the reason for this deviation.

As numerous (including own) investigations show [4, 5] even such smooth transient states as the ECE-15 R.83 are decisive about the emission level of $\mathrm{HC}, \mathrm{CO}$ and $\mathrm{NO}_{\mathrm{x}}$ in real systems. The modal analysis in this test has shown that:

- the mass share of the emission of $\mathrm{HC}, \mathrm{CO}, \mathrm{NO}_{\mathrm{x}}$ in the transient states of the test in the collective emission (from the entire test) measured before the catalyst amounted to approximately $60 \%$ for all the compounds and was higher than it would result from the time share of these states
Pierwsza składowa, tj. $T_{k}(\lambda)$ utrzymuje w zadanych stanach silnika skład mieszanki $\lambda$ na poziomie $\lambda^{*}=1$, co w zasadniczym stopniu decyduje o poziomie poszczególnych toksycznych składników w spalinach wg (1). Druga składowa wektora regulacji, tj. $\delta_{k}\left(i_{c}\right)$ poszukuje maksymalnej, energetycznej wydajności procesu w wyniku poszukiwania maksymalnego (dopuszczalnego graniczną wartością $i_{c}$ ) momentu silnika. W pierwszym przypadku system działa $\mathrm{w}$ układzie stabilizacji stałowartościowej $\left(\lambda^{*}=1\right)$, w drugim w układzie regulacji ekstremalnej $\mathrm{M}\left(\delta^{\mathrm{E}}\right)=$ maks.

\section{Cechy sterowania w badanym silniku}

W silniku użytym do badań sterowanie początkowe $\vec{U}_{0}$ wg (10) wyznacza stan początkowy $\overrightarrow{\mathrm{X}}_{0}$ w wyniku realizacji wtrysku początkowego $\mathrm{T}_{0}$ oraz kąta wyprzedzenia zapłonu $\delta$, wykorzystując w tym celu:

- prędkość obrotową silnika n,

- ciśnienie w zbiorczej części kolektora dolotowego $\mathrm{p}_{\Sigma}$,

- temperaturę bloku silnika $v_{\mathrm{E}}$.

Sterowanie korygujące 1-wymiarowe $\vec{U}_{\mathrm{k}}$ wg (11) stabilizuje skład mieszanki na poziomie $\lambda^{*}=1,0 \mathrm{w}$ tych wszystkich przypadkach, w których sterowanie początkowe $\vec{U}_{0}$ wg map nie zapewnia (z różnych przyczyn) oczekiwanego składu mieszanki.

Należy oczekiwać, że sterowanie mieszane $\vec{U}_{\mathrm{s}}$ wg (6) będzie korzystne, ponieważ wykorzystuje ono:

- w stanach przejściowych sterowanie otwarte $\vec{U}_{0}$ wg (10) zapewniające większą niż w układzie regulacji szybkość ustawiania początkowego stanu obiektu $\overrightarrow{\mathrm{X}}_{0}$, ograniczoną jedynie szybkością pomiaru parametrów stanu $\overrightarrow{\mathrm{Y}}_{0}$ i szybkością pracy urządzeń wykonawczych,

- w stanach ustalonych sterowanie zamknięte $\vec{U}_{k}$ wg (11) z użyciem sondy lambda, które powinno eliminować uchyb składu mieszanki niezależnie od źródła jego pochodzenia.

Jak wykazują liczne badania, w tym badania własne [4, 5], nawet tak „łagodne” stany przejściowe jak w teście ECE15 R.83 mają w realnych systemach decydujący wpływ na poziom emisji $\mathrm{HC}, \mathrm{CO}$ i NO . Analiza modalna w tym teście wykazała m.in., że:

- udział masowej emisji $\mathrm{HC}, \mathrm{CO}, \mathrm{NO}_{\mathrm{x}}$ w stanach przejściowych testu w łącznej emisji (z całego testu) mierzonej przed katalizatorem wyniósł dla wszystkich emitentów ok. $60 \%$ i był większy niż by to wynikało z czasowego udziału tych stanów (42\%) w łącznym czasie trwania testu, co świadczy o wzroście stężeń w stanach przejściowych,

- efektywność katalizatora w stanach przejściowych testu, obliczona ze stężeń za i przed katalizatorem jest prawie zerowa.

Wnioski te wskazują bądź na niewłaściwą strategię sterowania realizowaną przez ten system, bądź niewystarczającą 
$(42 \%)$ in the total duration of the test, which confirms a growth in the concentrations in the transient states,

- the efficiency of the catalytic converter in the transient states of the test calculated from the concentrations before and after the catalyst is almost zero.

These conclusions indicate either bad control strategy realized by this system or insufficient quality of exemplification. In the extended investigations [5] in selected transient states in the ECE-15 R.83 test a lack of a permanent bond of both flows $\mathrm{m}_{\mathrm{a}}$ and $\mathrm{m}_{\mathrm{f}}$, has been proved, which resulted in a fluctuation of the mixture composition in these states.

\section{Test results analysis}

The test results presented in [5] were prepared with the use of a mass air flow meter having an insufficient measurement speed for this test which limited the quantitative analysis of the problem to certain engine speeds and loads [6].

The here presented tests results follow the tests that use a mass flow meter developed by the authors, enabling a performance of the tests in a full range of engine speeds and loads of a tested engine [7]. The results analysis was performed applying the method of mixture composition fluctuation assessment in the cycle by cycle mode (the relevant paper is being prepared for publication). In this method the following have been defined:

- average preset mixture composition $\lambda^{\mu}$,

- average spread $\Delta \lambda^{\mu}{ }_{j}$ of the preset, cycle by cycle mixture composition,

- maximum spread $\lambda^{\mu}{ }_{i}$ of the preset, cycle by cycle mixture composition.

The fluctuation of the mixture composition was evaluated under steady states, represented by five typical engine operating and transient states represented by the engine rev up and rev down in the variants with and without a load.

In the investigations on the control system in the steady states (Fig. 3, Table 1) it is difficult to clearly determine in which of the analyzed sets $\mathrm{z} 1-\mathrm{z} 5$ a subsystem of oxygen sensor based adjustment was active. When analyzing the average values of the preset mixture composition $\lambda^{\mu}{ }_{j}$ we can only suppose that these were sets z2 and z3. These are the states of low and medium engine loads. In both cases the average preset mixture composition differs from the expected composition $\lambda^{*}=1 \pm 0.003$ so much that the efficiency of conversion of a three way catalyst is significantly reduced. Particularly low evaluation refers to the control in set z2, which is characterized (beside z4) by the largest spreads of the mixture composition (average and maximum).

In the other cases ( $z 1, z 4$ and $z 5)$ the highest fluctuation of the preset mixture composition measured with the spreads (average and maximum) occurs in the engine with a low load operating at high engine speeds $(\mathrm{z} 4)$. The preset mixture composition is in this case very rich $\left(\lambda^{\mu}{ }_{j}=0.714\right)$ which could result in a misfire and a high fluctuation of the output mixture composition and other related consequences.

The analysis of the cycle by cycle fuel mass $\mathrm{F}_{\mathrm{i}}$ determined for this case (Fig. 4) in relation to the cycle by cycle mixture composition $\lambda^{\mu}{ }_{i}$ indicates a structural fault of the opened control consisting in the adjustment of the mixture composition after the fact as the determined and injected fuel jakość jego egzemplifikacji. W badaniach rozszerzających [5] wykazano dla wytypowanych stanów przejściowych w teście ECE-15 R.83 brak zachowania stałej więzi obydwóch przepływów $\mathrm{m}_{\mathrm{a}}$ i $\mathrm{m}_{\mathrm{f}}$, co skutkowało fluktuacją składu mieszanki w tych stanach.

\section{Analiza wyników badań}

Wyniki badania przedstawione w [5] wykonano z zastosowaniem miernika masowego wydatku powietrza o niewystarczającej dla badanego przepływu szybkości pomiaru, co pozwoliło na wykonanie analizy ilościowej problemu tylko w ograniczonym zakresie prędkości obrotowej i obciążenia silnika [6].

Prezentowane w tej publikacji rezultaty są wynikiem badań z użyciem opracowanego we własnym zakresie miernika masowego wydatku powietrza, umożliwiającego wykonanie badań w pełnych zakresach prędkości i obciążenia badanego silnika [7]. Analizę wyników wykonano z zastosowaniem metody oceny fluktuacji składu mieszanki w relacji z cyklu na cykl (publikacja na ten temat jest przygotowywana do druku), w której zdefiniowano m.in.:

- średni skład wysterowany $\lambda^{\mu}$,

- rozrzut średni $\Delta \lambda^{\mu}{ }_{\mathrm{j}}$ wysterowanego, cyklowego składu,

- rozrzut maksymalny $\Delta \lambda^{\mu}{ }_{i}$ wysterowanego, cyklowego składu.

Fluktuację składu oceniano w stanach ustalonych, reprezentowanych przez pięć typowych stanów eksploatacyjnych silnika oraz w stanach przejściowych reprezentowanych

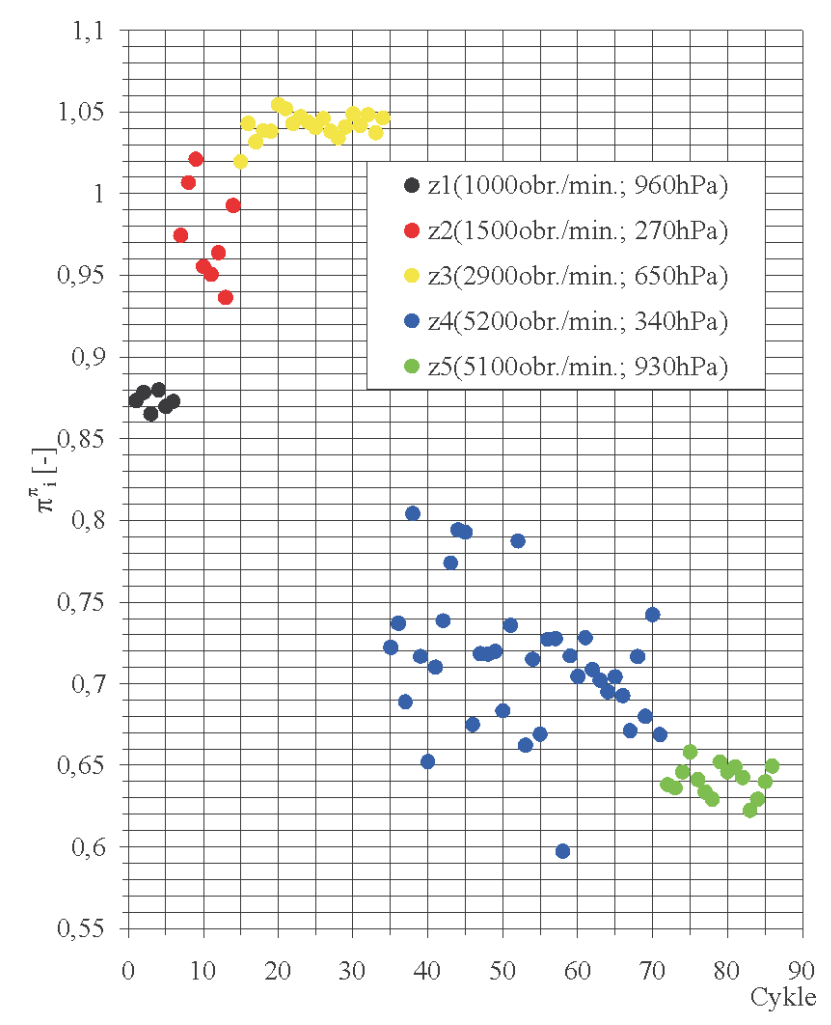

Fig. 3. Preset, cycle by cycle mixture composition in the fourth cylinder in the engine steady states

Rys. 3. Wysterowany, cyklowy sklad mieszanki w czwartym cylindrze w stanach ustalonych silnika 
Table 1. Indexes of fluctuation of the mixture composition in the engine (see Fig. 3)

Tabela 1. Wskaźniki fluktuacji składu mieszanki w stanach ustalonych w silniku (dotyczy rys. 3)

\begin{tabular}{|c|c|c|c|c|c|}
\hline $\mathrm{z}$ & $\mathrm{n}_{\mathrm{j}}$ & $\mathrm{p}_{\mathrm{j}}$ & $\lambda_{{ }_{i}}$ & $\Delta \lambda^{\mu}{ }_{\mathrm{i}}$ & $\Delta \lambda_{j}^{\mu}$ \\
\hline $\mathrm{z} 1$ & 1025 & 964 & 0.873 & 0.014 & 0.008 \\
\hline $\mathrm{z} 2$ & 1514 & 270 & 0.975 & 0.085 & 0.051 \\
\hline $\mathrm{z} 3$ & 2910 & 646 & 1.042 & 0.035 & 0.011 \\
\hline $\mathrm{z} 4$ & 5199 & 344 & 0.714 & 0.207 & 0.061 \\
\hline $\mathrm{z} 5$ & 5113 & 930 & 0.641 & 0.036 & 0.015 \\
\hline
\end{tabular}

mass $F_{i}$ in the $i$-th cycle influences the value of the preset mixture composition $\lambda^{\mu}{ }_{i}$ in $(i+1)$-th cycle. The change in the air filling that could occur in the cycle right after fuel dose $F_{i}$ is injected will deviate the mixture from the preset one.

Its adjustment will take place only in the next cycle assuming that the air filling conditions do not change. Otherwise the preset mixture composition will still be different from the expected one.

If for any reasons the air filling in the fourth cycle that amounts to $98.22 \mathrm{mg}$ drops in the fifth cycle to $97.37 \mathrm{mg}$ then in order to preserve the repeatability of the mixture composition in cycle 4 and $5\left(\lambda_{5}=\lambda_{4}=0.805\right)$ the fuel dose in the fifth cycle should drop in comparison to the fourth cycle by $0.072 \mathrm{mg}$ instead of growing by $0.9 \mathrm{mg}$ which denotes an overdose of more than twelve times of the fuel from cycle 4 to 5 . Because in this engine state the flow conditions in the

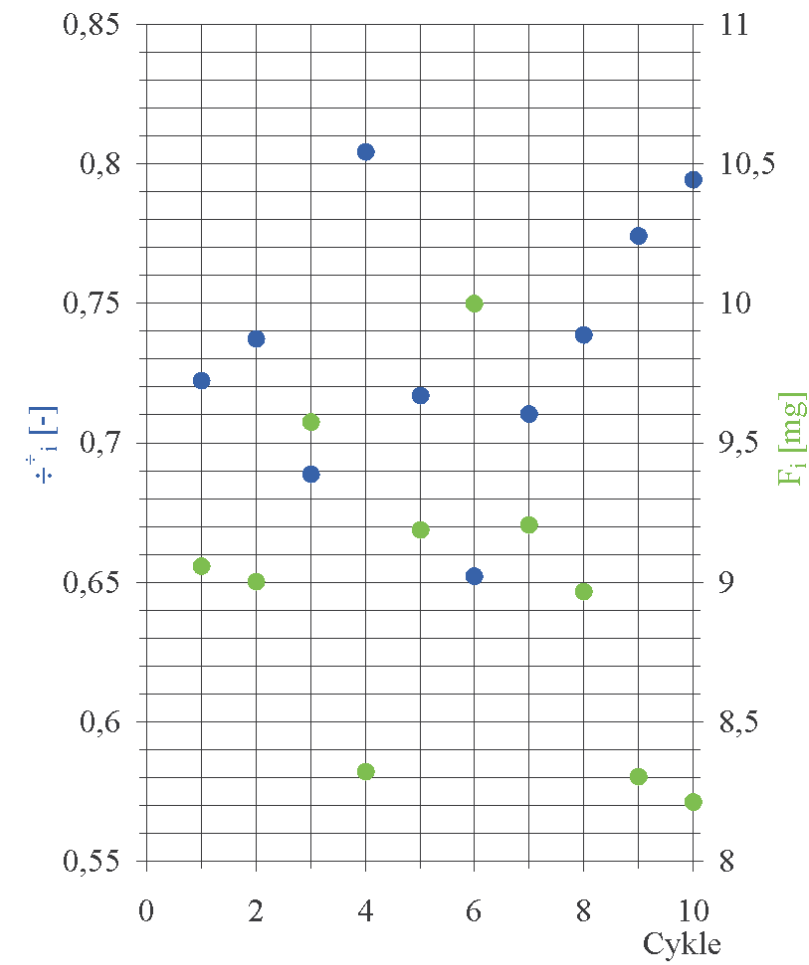

Fig. 4. Codependence of the preset, cycle by cycle mixture composition and the injected cycle by cycle fuel mass $\mathrm{F}_{\mathrm{i}}$ in ten consecutive ignition cycles from set $\mathrm{z} 4$

Rys. 4. Wspólzależność wysterowanego, cyklowego składu mieszanki $i$ wtryśniętej do kolektora dolotowego cyklowej masy paliwa $F_{i}$ $w$ dziesięciu kolejnych cyklach ze zbioru z4 przez rozbieg i wybieg silnika w wariantach z zadanym obciążeniem i bez obciążenia.

W badaniach systemu sterowania w stanach ustalonych (rys. 3, tab. 1) trudno jest jednoznacznie określić na ich podstawie, w których $\mathrm{z}$ analizowanych zbiorów z1-z5 aktywny był podsystem regulacji $z$ sondą lambda. Analizując wartości średnie wysterowanego składu $\lambda^{\mu}$ można jedynie przypuszczać, że były to zbiory z2 i z3. Są to stany niskich i średnich obciążeń silnika. W obydwóch przypadkach średni skład wysterowany różni się jednak na tyle od składu oczekiwanego $\lambda^{*}=1 \pm 0,003$, że efektywność konwersji trójfunkcyjnego reaktora katalitycznego będzie istotnie obniżona. Szczególnie negatywna ocena dotyczy sterowania w zbiorze z2, który charakteryzuje się (obok z4) największymi rozrzutami średnim i maksymalnym składu mieszanki.

W pozostałych przypadkach (z1, z4 i z5) największa fluktuacja wysterowanego składu mierzona rozrzutami średnim i maksymalnym występuje w silniku niskoobciążonym, pracującym z wysoką prędkością obrotową (z4). Skład wysterowany jest w tym przypadku bardzo bogaty $\left(\lambda^{\mu}{ }_{j}=0,714\right)$, co może skutkować wypadaniem zapłonów i powodować m.in. wysoką fluktuację składu wyjściowego mieszanki oraz inne związane z tym skutki.

Analiza wyznaczonej dla tego przypadku (rys. 4) masy cyklowej paliwa $\mathrm{F}_{\mathrm{i}} \mathrm{w}$ powiązaniu $\mathrm{z}$ cyklowym składem mieszanki $\lambda^{\mu}{ }_{i}$ wskazuje na strukturalną wadę sterowania otwartego, polegającą na korekcie składu mieszanki przez to sterowanie w trybie post factum, ponieważ wyznaczona $\mathrm{i}$ wtryśnięta $\mathrm{w}$ i-tym cyklu masa paliwa $\mathrm{F}_{\mathrm{i}}$ wpływa na wartość wysterowanego składu mieszanki $\lambda^{\mu}{ }_{i} \mathrm{w}(\mathrm{i}+1)$-tym cyklu. Zmiana napełnienia powietrzem, która może wystąpić $\mathrm{w}$ tym cyklu już po wtrysku dawki $\mathrm{F}_{\mathrm{i}}$ odchyli skład mieszanki od zaprogramowanego.

Jego korekta nastąpi dopiero w następnym cyklu przy założeniu, że warunki napełniania powietrzem w tym czasie nie ulegną zmianie. W przeciwnym przypadku skład wysterowany będzie wciąż różny od oczekiwanego.

Jeżeli z dowolnych przyczyn napełnienie powietrzem w cyklu czwartym wynoszące 98,22 mg spadnie w cyklu piątym do poziomu $97,37 \mathrm{mg}$, to $\mathrm{w}$ celu zachowania niezmienności składu mieszanki w cyklach 4 i $5\left(\lambda_{5}=\lambda_{4}=\right.$ $=0,805)$ dawka paliwa $\mathrm{w}$ cyklu piątym powinna zmniejszyć się w stosunku do dawki w cyklu czwartym o 0,072 mg, zamiast wzrosnąć o $0,9 \mathrm{mg}$, co oznacza ponad dwunastokrotne przedawkowanie (zawyżenie) paliwa z cyklu 4 na 5. Ponieważ w tym stanie pracy silnika warunki przepływowe w kolektorze są quasi-statyczne, nie zaburzające stanu filmu paliwowego, nie było więc uzasadnienia dla tak istotnego wzbogacenia mieszanki ( $\mathrm{z} \lambda=0,805$ do $\lambda=0,715$ ).

W stanach przejściowych (rys. 5 i 6 ) największą fluktuację składu mieszanki zidentyfikowano dla silnika nieob- 

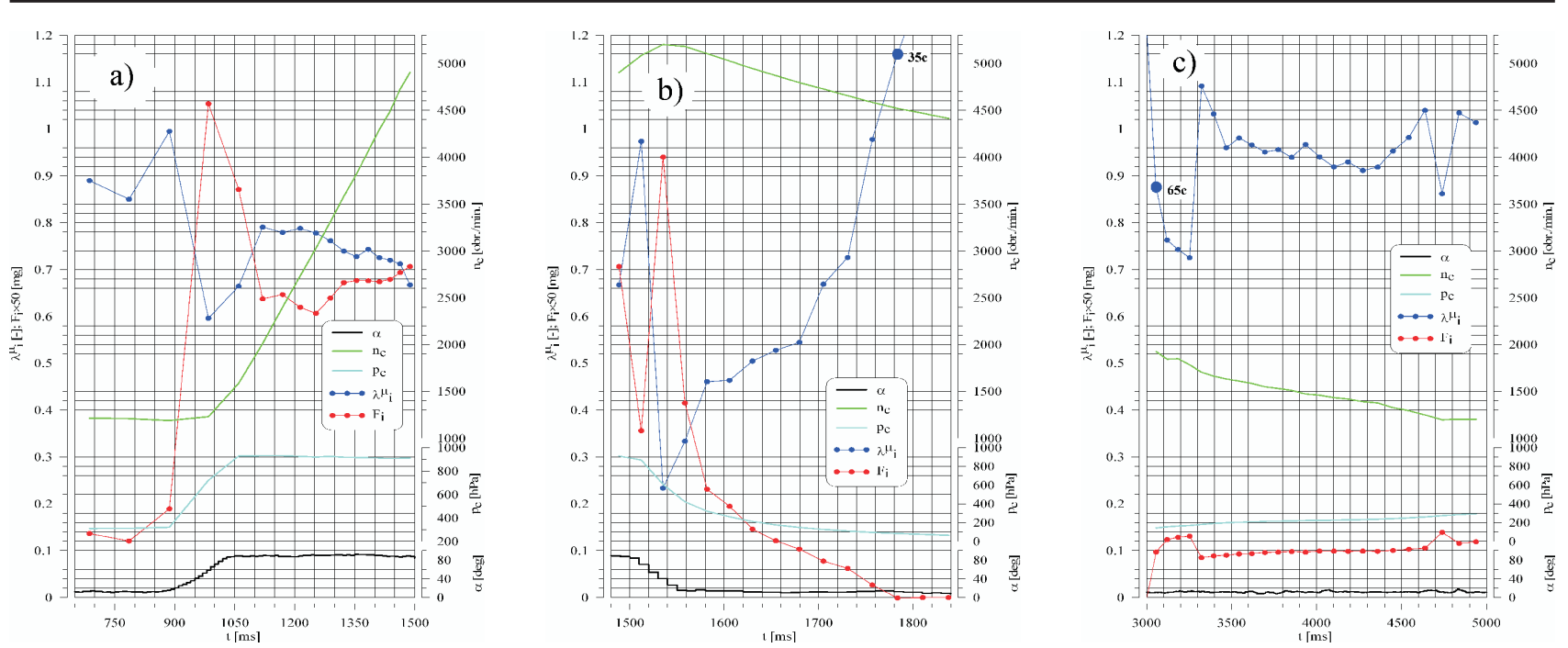

Fig. 5. The fluctuation of the preset, cycle by cycle mixture composition against the parameters characterizing the engine state in the fourth cylinder of an engine without a load in the states of: a) rev up, b) rev down before the injector is deactivated, c) rev down after the injector is activated

Rys. 5. Fluktuacja wysterowanego, cyklowego składu mieszanki na tle parametrów charakteryzujacych stan pracy w czwartym cylindrze silnika nieobciązonego w stanach: a) rozbiegu, b) wybiegu przed odtaczeniem wtryskiwacza, c) wybiegu po właczeniu wtryskiwacza

manifold are quasi-static, not disturbing the fuel film there is no justification for such a high mixture enrichment (from $\lambda=0.805$ to $\lambda=0.715$ ).

In the transient states (Fig. 5 and 6) the highest fluctuation of the mixture composition was identified for an engine without a load. Such a situation occurs for all three phases of these states:

- the rev up phase to a speed a bit lower than the speed of injector cut off (Fig. 5a and 6a),

- engine brake phase i.e. this part of the rev down phase when the injectors are active even though the throttle is already closed (Fig. 5b and 6b),

- the free rev down phase i.e. the phase with a under-expanded intake and activated injectors (Fig. 5c and 6c).

In the rev up phase (Fig. 5a and 6a) the injector opening time has a nature of fading oscillations of very high initial over-adjustment. The injection oscillation triggers similar oscillations of the mixture composition, which could indicate a prevailing influence of the cycle by cycle fuel dose $F_{i}$ on this composition. In both tests the rev up phase is characterized by an enriched mixture of high spreads - maximum $\lambda^{\mu}{ }_{\mathrm{i}}$ and average $\lambda^{\mu}{ }_{j}$ (Table 2 and 3 ).

In the first part of

Table 2. Indexes of the fluctuation of the mixture composition in the rev up and rev down states of an engine

Tabela 2. Wskaźniki fluktuacji składu mieszanki w stanach rozbiegu i wybiegu silnika nieobciążonego (dotyczy rys. 5)

\begin{tabular}{|c|c|c|c|c|c|c|c|}
\hline Fig & $\mathrm{n}_{\mathrm{S}}$ & $\mathrm{n}_{\mathrm{F}}$ & $\mathrm{p}_{\mathrm{S}}$ & $\mathrm{p}_{\mathrm{F}}$ & $\lambda_{\mathrm{j}}{ }_{\mathrm{j}}$ & $\Delta \lambda_{{ }_{\mathrm{i}}}$ & $\Delta \lambda_{\mathrm{j}}{ }_{\mathrm{j}}$ \\
\hline 5a & 1214 & 4092 & 309.8 & 911.4 & 0.774 & 0.549 & 0.175 \\
\hline $5 \mathrm{~b}$ & 4092 & 4412 & 911.4 & 65.6 & 0.597 & 0.780 & 0.375 \\
\hline $5 \mathrm{c}$ & 1925 & 1202 & 143.2 & 292.6 & 0.947 & 0.375 & 0.123 \\
\hline
\end{tabular}

the rev up phase i.e. from the moment the throttle begins to close until the moment the injector is deactivated (Fig. $5 \mathrm{~b}$ and $6 \mathrm{~b}$ ) the fluctuation of the mixture composition is the highest of all the analyzed transient states and is almost one order of magnitude larger than it is for the steady state of the highest fluctuation of the mixture composition (z4). In this phase the cycle by cycle changes in the injection duration are without a load (see Fig. 5)

ciążonego. Taka sytuacja ma miejsce we wszystkich trzech fazach tych stanów:

- fazy rozbiegu do prędkości nieco mniejszej od prędkości odcięcia wtryskiwaczy (rys. 5a i 6a),

- fazy hamowania silnikiem, tj. tej części fazy wybiegu, w której wtryskiwacze są aktywne pomimo zamknięcia przepustnicy (rys. 5b i 6b),

- fazy swobodnego wybiegu, tj. fazy przy odprężonym dolocie i przy włączonych ponownie wtryskiwaczach (rys. $5 \mathrm{c}$ i $6 \mathrm{c})$.

W fazie rozbiegu (rys. 5a i 6a) czas otwarcia wtryskiwacza ma charakter zanikających oscylacji o bardzo dużym, pierwszym przeregulowaniu. Oscylacje wtrysku wywołują podobne w charakterze oscylacje składu mieszanki, co może wskazywać na przeważający wpływ cyklowej dawki paliwa $F_{i}$ na ten skład. $W$ obydwóch badaniach faza rozbiegu cechuje się mieszanką wzbogaconą o dużych rozrzutach maksymalnym $\lambda^{\mu}{ }_{i}$ i średnim $\lambda^{\mu}{ }_{j}($ tab. 2 i 3).

W pierwszej części fazy wybiegu, tj. od rozpoczęcia zamykania przepustnicy do wyłączenia wtryskiwacza (rys. 5b i 6b), fluktuacja składu jest największa ze wszystkich analizowanych stanów przejściowych i jest ona prawie o jeden rząd większa niż dla stanu ustalonego o największej fluktuacji składu (z4). W fazie tej zmiany czasu wtrysku z cyklu na cykl maja charakter zanikający, przy czym dla silnika 
of a fading nature and, for the engine without a load, two cycle oscillations occur, which is probably a result of incidental change in the throttle position.

The fluctuation of the mixture composition in the phase starting from the deactivation of the injectors (cycle 35 in Fig. $5 \mathrm{~b}$ and cycle 38 in Fig. $6 \mathrm{~b}$ ) to their reactivation (cycle 65 in Fig. 5c and cycle 92 in Fig. $6 c)$ has not been analyzed because the control in this state does not affect the fluctuation of the mixture composition. In this state however, the mixture composition reaching the catalytic converter will be very important as it will allow an assessment of the dynamics of the fuel film fading as a result
Table 3. Indexes of the fluctuation of the mixture composition in the rev up and rev don states of an engine with a load (see Fig. 6)

Tabela 3. Wskaźniki fluktuacji składu mieszanki w stanach rozbiegu i wybiegu silnika obcią̇̇onego (dotyczy rys. 6)

\begin{tabular}{|c|c|c|c|c|c|c|c|}
\hline Fig & $\mathrm{n}_{\mathrm{S}}$ & $\mathrm{n}_{\mathrm{F}}$ & $\mathrm{p}_{\mathrm{S}}$ & $\mathrm{p}_{\mathrm{F}}$ & $\lambda_{{ }_{\mathrm{j}}}$ & $\Delta \lambda^{\mu}{ }_{\mathrm{i}}$ & $\Delta \lambda_{\mathrm{j}}{ }_{\mathrm{j}}$ \\
\hline $6 \mathrm{a}$ & 942 & 4015 & 387 & 913,2 & 0,820 & 0,489 & 0,164 \\
\hline $6 \mathrm{~b}$ & 4128 & 4056 & 910,4 & 70,6 & 0,854 & 0,664 & 0,311 \\
\hline $6 \mathrm{c}$ & 1982 & 1009 & 142,6 & 367,8 & 1,000 & 0,409 & 0,092 \\
\hline
\end{tabular}

nieobciążonego miały miejsce 2-cyklowe jego oscylacje, co prawdopodobnie było skutkiem przypadkowych przestawień przepustnicy. Nie analizowano fluktuacji składu mieszanki w fazie od wyłączenia wtryskiwaczy (cykl 35 na rys. 5b i cykl 38 na rys. 6b) do ich ponownego załączenia (cykl 65 na rys. 5 c i cykl 92 na rys. 6c), ponieważ sterowanie w tym stanie nie ma wpływu na fluktuację składu. Bardzo ważny będzie jednak w tym stanie skład mieszanki docierającej do reaktora
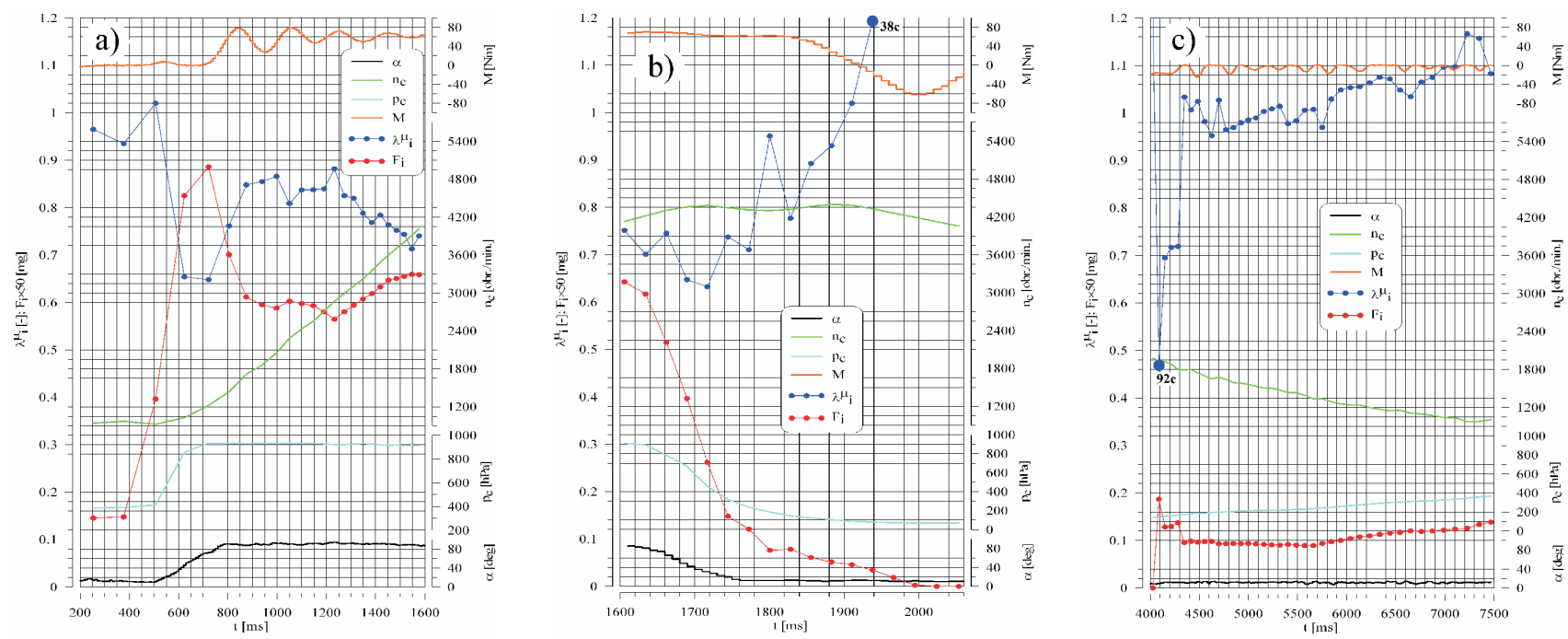

Fig. 6. The fluctuation of the preset, cycle by cycle mixture composition against the parameters characterizing the engine state in the fourth cylinder of a loaded engine: a) rev up, b) rev down before the injector is deactivated, c) rev down after the injector is activated

Rys. 6. Fluktuacja wysterowanego, cyklowego składu mieszanki na tle parametrów charakteryzujacych stan pracy w czwartym cylindrze silnika obciażonego dla: a) rozbiegu, b) wybiegu przed odtaczeniem wtryskiwacza, c) wybiegu po właczeniu wtryskiwacza

of the sucking off of the fuel from the intake manifold. It is a subject of further research whose results are being prepared for publication.

In the final part of the rev down phase (Fig. 5c and 6c) we can see a four cycle enhanced fuel injection and then it gets stabilized along with other quantities (n, p).

The basic questions still lacking answers after this stage of the investigations are related to:

- the oscillatory character of the changes in the injection durations in the rev up phase,

- the expected way of fuel dosage fade in the first part of the rev down.

These two questions set the trend in the research aiming at ensuring such a character of these courses, that the toxic components flowing through the catalytic converter are converted with the highest possible efficiency. katalitycznego, ponieważ pozwoli to na ocenę dynamiki zanikania filmu paliwowego $\mathrm{w}$ wyniku wysysania paliwa $\mathrm{z}$ kolektora dolotowego. Jest to przedmiotem dalszych badań, których wyniki są przygotowane do opublikowania.

W końcowej części fazy wybiegu (rys. 5c i 6c) widoczny jest 4-cyklowy, zwiększony wtrysk paliwa, po czym ma miejsce stabilizacja jego i innych wielkości (n, p).

Zasadnicze pytania, na które brak odpowiedzi po tym etapie badań dotyczą:

- oscylacyjnego charakteru zmian długości wtrysku w fazie rozbiegu,

- oczekiwanego sposobu zanikania dawkowania w pierwszej części fazy wybiegu.

Te dwa pytania wyznaczają kierunek badań prowadzonych w celu zapewnienia takiego charakteru tych przebiegów, aby toksyczne składniki w spalinach przepływające 


\section{Conclusions}

The fluctuation of a preset mixture compositions in an indirect injection spark ignition engine is:

- in steady states:

a) lower as the engine load gets higher, irrespective of the engine speed,

b) the lowest for the highest loads ( $930 \mathrm{hPa}$ and $960 \mathrm{hPa}$ ) - probably as a result of a disconnection of the oxygen sensor sub system,

c) high for part loads $(270 \mathrm{hPa})$ despite active control with the oxygen sensor,

d) particularly high probably on the boundary of the operating states with and without the use of the oxygen sensor $(340 \mathrm{hPa} / 5200 \mathrm{rpm})$,

- in transient states:

e) in the rev up state, dependent on the engine load: the higher the load the lower the fluctuation,

f) the highest in the first phase of the rev down, i.e. from the moment the throttle begins to close until the fuel is not injected anymore. przez trójfunkcyjny reaktor katalityczny były konwertowane z największą sprawnością katalizatora.

\section{Wnioski}

Fluktuacja wysterowanego, cyklowego składu mieszanki w silniku iskrowym $\mathrm{z}$ wtryskiem pośrednim jest:

- w stanach ustalonych:

a) tym mniejsza, im większe jest obciążenie silnika, niezależnie od prędkości obrotowej,

b) najmniejsza dla obciążeń najwyższych (930 hPa i 960 $\mathrm{hPa}$ - prawdopodobnie w wyniku odłączenia podsystemu z sondą lambda,

c) wysoka dla obciążeń częściowych (270 hPa) pomimo aktywnego sterowania $z$ sondą lambda,

d) szczególnie wysoka, prawdopodobnie na granicy stanów z udziałem i bez udziału sondy lambda $(340 \mathrm{hPa} / 5200 \mathrm{obr} / \mathrm{min})$

- w stanach przejściowych:

e) w stanie rozbiegu zależna od obciążenia silnika: im obciążenie jest większe, tym fluktuacja jest mniejsza,

f) największa w pierwszej części fazy wybiegu, tj. od rozpoczęcia zamykania przepustnicy do zaprzestania wtryskiwania paliwa.

Paper reviewed

\section{Bibliography/Literatura}

[1] Adler U., Bauer H.: Automotive Electric/ Electronic Systems, Robert Bosch GmbH, Stuttgart 1988.

[2] Nita J., Schubring T.: Aspects of Computational Complexity of the Methods for the Calculation of Two-Dimensional Control for a Petrol Engine in the EUDC-Test, FISITA World Automotive Congress, SEOUL, Korea 2000.

[3] Nita J.: Kalibracja statyczna i sterowanie silnikiem iskrowym, XI Ogólnopolskie Sympozjum Naukowe SYMROZ, Szczecin 2009.

[4] Metoda wyznaczania czasu wtrysku i kąta wyprzedzenia zapłonu w silniku benzynowym na przykładzie rozszerzonego testu ECE-15. Sprawozdanie z projektu własnego KBN nr 9T12D02014/N. Politechnika Radomska 2000.

Mr. Józef Nita, DSc., DEng. - Professor in the Faculty of Mechanical Engineering at Radom University of Technology.

Dr hab. inż. Józef Nita - profesor na Wydziale Mechanicznym Politechniki Radomskiej.

e-mail: j_nita@o2.pl
[5] Nita J., Wołczyński Z.: Ocena pracy wielopunktowego systemu sterowania wtryskiem paliwa $\mathrm{w}$ stanach przejściowych, w aspekcie ekologicznym na przykładzie silnika samochodu POLONEZ. Kones 2000.

[6] Nita J.: Determination of Cylinder Filling to Control Fuel Injection, 11-th EAEC European Automotive Congress, Budapest 2007.

[7] Rozwój sposobu sterowania składem mieszanki z cyklu na cykl na przykładzie silnika benzynowego. Sprawozdanie z projektu własnego MNiSW nr 4 T12D 009 27. Politechnika Radomska 2007. 